\title{
Phosphatase-1-inhibitor-1: amplifier or attenuator of catecholaminergic stress?
}

\author{
Katrin Wittköpper • Thomas Eschenhagen • \\ Ali El-Armouche
}

Received: 18 May 2010/Revised: 19 May 2010/Accepted: 20 May 2010/Published online: 6 June 2010

(C) The Author(s) 2010. This article is published with open access at Springerlink.com

Sympathetic stimulation of myocardial $\beta$-adrenergic receptors $(\beta-\mathrm{AR})$ represents the most powerful mechanism to acutely increase cardiac output. In the clinical course of heart failure, adrenergic stimulation initially serves to compensate for contractile dysfunction, but in the chronic hyperadrenergic state, it finally results in deterioration of cardiac function and structure. This sympathetic dysregulation is one of the best documented paradigms in cardiovascular medicine and has been underscored by clinical trials demonstrating remarkable benefit from chronic $\beta$-AR blockade. However, the positive effects of $\beta$-AR blockers appear paradoxical since these drugs initially further compromise contractile performance. The lesson learned is that $\beta$-AR signaling represents a biologically flexible system that adapts quickly to overstimulation by a process termed " $\beta$-AR desensitization". This phenomenon is typical for failing hearts and is regarded mainly as a protective mechanism of adaptation [4]. It involves decreased numbers of myocardial $\beta_{1}$-ARs as well as increased levels of G-proteincoupled receptor kinases (GRK2) and inhibitory G-proteins $\left(\mathrm{G}_{\mathrm{i}}\right)$ [1]. However, more recently it became clear that "desensitization" is a reversible process and "resensitization" occurs after catecholamine withdrawal. Accordingly, $\beta$-AR blockers "resensitize" the failing heart and improve exercise tolerance in patients and are associated with

\footnotetext{
K. Wittköpper · A. El-Armouche $(\square)$

Department of Pharmacology, University Medical Center

Göttingen, Georg August University Göttingen,

Robert-Koch-Str. 40, 37075 Göttingen, Germany

e-mail: ali.el-armouche@med.uni-goettingen.de

T. Eschenhagen

Department of Experimental and Clinical Pharmacology,

University Medical Center Hamburg Eppendorf,

Hamburg, Germany
}

normalization of $\beta_{1}$-ARs, GRK2 and $G_{i}$ levels in cardiomyocytes. Besides the direct reduction of catecholaminemediated toxic effects on the heart normalization of $\beta$-AR signaling might be an additional major beneficial mechanism of $\beta$-AR blockers. Thus, there is strong rationale for therapeutic strategies aiming to either inhibit the $\beta$-AR system or to restore its physiological sensitivity in heart failure.

In addition to dysregulated $\beta_{1}$-ARs, GRK2 and $\mathrm{G}_{\mathrm{i}}$, there is a downregulation and deactivation of phosphatase-1inhibitor-1 (I-1), an intracellular phospho-protein that has been recently implicated in $\beta$-AR desensitization $[2,5,6]$. Upon phosphorylation by PKA, I-1 acts as an amplifier element of $\beta$-AR signaling by preventing dephosphorylation of downstream targets by type-1 phosphatases (PP-1). However, whether this finding should be viewed as a protective or adverse response is controversial and therapeutic strategies that either inhibit endogenous I-1 activity or increase its activity by expressing a constitutively active I-1 mutant form (I-1c) are currently extensively investigated.

In this issue of Basic Research in Cardiology, Chen et al. [3] investigated the effects of transgenic heart-specific I-1c expression on apoptosis in the well-characterized isoprenaline-infusion heart failure model. The authors observed less cardiac apoptosis and preserved contractile function in the transgenic I-1c hearts compared to wild type. This was associated with changes in protein abundance and phosphorylation level of several apoptosisrelated proteins. The overall conclusion from the present study is consistent with previous work reporting that I-1c transgenic mice exhibit better contractility and attenuated deterioration of cardiac structure in models of chronic cardiac pressure overload and ischemia/reperfusion injury, respectively $[9,11]$. 
Recent work from our group, however, shows that I-1 deleted mice (I-1 KO) were protected from catecholamineinduced arrhythmias and progression to heart failure in a very similar experimental approach setting [7]. Moreover, again using the chronic catecholamine infusion model, we observed exaggerated contractile dysfunction, ventricular dilation and fibrosis in conditional I-1c expressing mice generated on an I-1 KO background. These changes were reversible after shutting off I-1c expression by doxycycline (Tet-Off-system) providing evidence for a direct causal relationship [12]. Notably, the I-1c expressing mice developed a cardiomyopathic phenotype with aging [8, 12]. Thus, this recent set of data suggests that inhibition of I-1 protects the heart, whereas the current and previous data from the Kranias group support the idea of AAV-mediated I-1c expression as a new therapeutic approach in heart failure. At present it is not clear how these apparently opposing concepts can be integrated.

Despite almost identical I-1c expression levels $(\sim 25$-fold $)$ and very similar experimental conditions (14 days 30 vs. $50 \mathrm{mg} / \mathrm{kg} /$ day in this study), the two mice studies dealing with the role of I-1c in chronic catecholaminergic stress differ in important aspects. First, the genetic background in our study was C57B1/6J, whereas it was $\mathrm{FVB} / \mathrm{N}$ in the present study. It is well known that such strain differences can give rise to very different results. Second, different environmental factors in mouse husbandry could contribute. A straightforward solution would be to analyze the "other" mouse-model in the own laboratory with the corresponding backgrounds and vice versa. Third, and maybe most importantly, Chen et al. [3] expressed I-1c on top of endogenous I-1, whereas we expressed I-1c on an I-1 knockout background, i.e. in the absence of endogenous I-1. The reasoning was that, in the presence of endogenous I- 1 , the less potent $(\sim 8$-fold higher $\left.\mathrm{IC}_{50}[12]\right)$ but stoichiometrically dominating 25 -fold overexpressed I-1c would compete for binding to PP-1 with both phosphorylated (active) and non-phosphorylated (inactive) I-1 [10]. Whereas the former action would dampen the maximal effect of catecholamines (making I-1c a partial antagonist), the latter would lead to increased basal activity, making I-1c a partial agonist. Thus, the PP1-inhibiting effect of I-1c will depend on endogenous I-1 levels and its phosphorylation status and thus on the degree of cellular catecholaminergic stress. We considered this a complicated situation, but it may indeed explain why our results differ from that of the present and former studies.

Taken together, despite the substantial advance in our understanding of the role of this small $\beta$-AR amplifier in the heart, it is still unclear whether I-1 is a promising therapeutic target in heart failure and if yes, whether its activity/amount should be increased or decreased. In order to determine its real therapeutic value in heart failure, pharmacological agents are likely needed to modulate I-1 activity in the context of preexisting heart failure.

Acknowledgments The authors are supported by the Deutsche Forschungsgemeinschaft (DFG EL 270/3-1/2 to AEA and TE), the European Union (EUGene Heart to AEA and TE) and the German Heart Foundation (to AEA).

Open Access This article is distributed under the terms of the Creative Commons Attribution Noncommercial License which permits any noncommercial use, distribution, and reproduction in any medium, provided the original author(s) and source are credited.

\section{References}

1. Brodde OE, Bruck H, Leineweber K, Seyfarth T (2001) Presence, distribution and physiological function of adrenergic and muscarinic receptor subtypes in the human heart. Basic Res Cardiol 96:528-538

2. Carr AN, Schmidt AG, Suzuki Y, del Monte F, Sato Y, Lanner C, Breeden K, Jing SL, Allen PB, Greengard P, Yatani A, Hoit BD, Grupp IL, Hajjar RJ, DePaoli-Roach AA, Kranias EG (2002) Type 1 phosphatase, a negative regulator of cardiac function. Mol Cell Biol 22:4124-4135

3. Chen G, Zhou X, Florea S, Qian J, Cai W, Zhang Z, Fan GC, Lorenz J, Hajjar RJ, Kranias EG (2010) Expression of active protein phosphatase 1 inhibitor-1 attenuates chronic beta-agonistinduced cardiac apoptosis. Basic Res Cardiol (in press)

4. El-Armouche A, Eschenhagen T (2009) Beta-adrenergic stimulation and myocardial function in the failing heart. Heart Fail Rev $14: 225-241$

5. El-Armouche A, Gocht F, Jaeckel E, Wittkopper K, Peeck M, Eschenhagen $T$ (2007) Long-term beta-adrenergic stimulation leads to downregulation of protein phosphatase inhibitor-1 in the heart. Eur J Heart Fail 9:1077-1080

6. El-Armouche A, Pamminger T, Ditz D, Zolk O, Eschenhagen T (2004) Decreased protein and phosphorylation level of the protein phosphatase inhibitor-1 in failing human hearts. Cardiovasc Res 61:87-93

7. El-Armouche A, Wittkopper K, Degenhardt F, Weinberger F, Didie M, Melnychenko I, Grimm M, Peeck M, Zimmermann WH, Unsold B, Hasenfuss G, Dobrev D, Eschenhagen T (2008) Phosphatase inhibitor-1-deficient mice are protected from catecholamine-induced arrhythmias and myocardial hypertrophy. Cardiovasc Res 80:396-406

8. Leineweber K, Klapproth S, Beilfuss A, Silber RE, Heusch G, Philipp T, Brodde OE (2003) Unchanged G-protein-coupled receptor kinase activity in the aging human heart. J Am Coll Cardiol 42:1487-1492

9. Nicolaou P, Rodriguez P, Ren X, Zhou X, Qian J, Sadayappan S, Mitton B, Pathak A, Robbins J, Hajjar RJ, Jones K, Kranias EG (2009) Inducible expression of active protein phosphatase-1 inhibitor-1 enhances basal cardiac function and protects against ischemia/reperfusion injury. Circ Res 104:1012-1020

10. Oliver CJ, Shenolikar S (1998) Physiologic importance of protein phosphatase inhibitors. Front Biosci 3:D961-D972

11. Pathak A, del Monte F, Zhao W, Schultz JE, Lorenz JN, Bodi I, Weiser D, Hahn H, Carr AN, Syed F, Mavila N, Jha L, Qian J, Marreez Y, Chen G, McGraw DW, Heist EK, Guerrero JL, DePaoli-Roach AA, Hajjar RJ, Kranias EG (2005) Enhancement of cardiac function and suppression of heart failure progression by inhibition of protein phosphatase 1 . Circ Res 96:756-766 
12. Wittkopper K, Fabritz L, Neef S, Ort KR, Grefe C, Unsold B, Kirchhof P, Maier LS, Hasenfuss G, Dobrev D, Eschenhagen T, El-Armouche A (2010) Constitutively active phosphatase inhibitor-1 improves cardiac contractility in young mice but is deleterious after catecholaminergic stress and with aging. J Clin Invest 120:617-626 